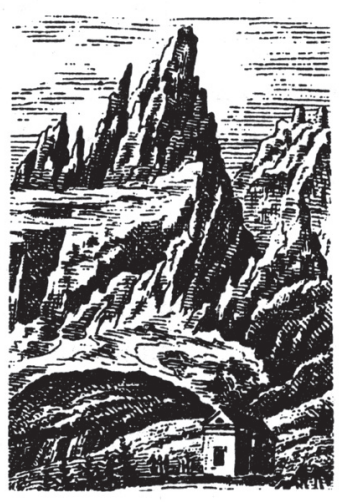

Ewa Grzęda

ORCID: 0000-0001-5254-9458

Uniwersytet Wrocławski

ewa.grzeda@uwr.edu.pl

ewagrzeda@02.pl

DOI: $10.19195 / 2084-4107.12 .10$

\title{
Romantyczne wędrówki Polaków po Szwajcarii Saskiej
}

Słowa-klucze: góry, literatura, podróż, Saska Szwajcaria

Keywords: mountains, literature, journey, Saxon Switzerland

\section{Romantic wanderings of Poles across Saxon Switzerland}

\section{Summary}

The history of Polish tourism in the Elbe Sandstone Mountains as well as the literary and artistic reception of the landscape and culture of Saxon Switzerland have never been discussed in detail. The present article is a research reconnaissance. The beginnings and development of tourism in the region came in the late 18th and early 19 th century. The 1800 s were marked by the emergence of the first German-language descriptions of Saxon Switzerland, which served as guidebooks at the time. From the very beginning Poles, too, participated in the tourist movement in the area. The author of the article seeks to follow the increasing interest in Saxon Switzerland and the appearance of the first descriptions of the region in Polish literature and culture. She provides a detailed analysis of Polish-language accounts of micro-trips to the Elbe Sandstone Mountains by Andrzej Edward Koźmian, Stanisław Deszert, Antoni Edward Odyniec, Klementyna Hoffman née Tańska 
and a poem by Maciej Bogusz Stęczyński. As the analysis demonstrates, in the first half of the 19th century Poles liked to visit these relatively low mountains in Central Europe and tourism in the region is clearly part of the history of Polish mountain tourism. Thanks to unique aesthetic and natural values of the mountains, full of varied rocky formations, reception of their landscape had an impact of the development of the aesthetic sensibility of Polish Romantics. Direct contact with nature and the landscape of Saxon Switzerland also served an important role in the shaping of spatial imagination of Polish tourists, encouraging them to explore other mountains in Europe and the world, including the Alps. On the other hand thanks to the development of tourist infrastructure in Saxon Switzerland, facilitating trips in the region and making the most attractive spots available to inexperienced tourists, micro-trips to the Elbe Sandstone Mountains marked an important stage in the development of mountain tourism on a popular-recreational level. Polish-language accounts of trips to Saxon Switzerland from the first half of the 20th century are a noteworthy manifestation of the beginnings of Polish travel literature.

Położone na terenie Saksonii Góry Połabskie, rozciągające się wzdłuż koryta Łaby (Elby), od XVIII wieku znane są także jako Saska Szwajcaria'; analogicznie ich fragment znajdujący się na obszarze Czech nazywany jest Czeską Szwajcarią. Obecnie owo rozległe pasmo gór stołowych określa się także mianem Sasko-Czeskiej Szwajcarii (die Sächsisch-Böhmische Schweiz). Tę skądinąd wartościującą nazwę, nawiązującą do utrwalającego się w XVIII wieku przekonania o pięknie alpejskich krajobrazów Helwecji, region ten zawdzięcza dwóm szwajcarskim malarzom: Adrianowi Zingowi i Antonowi Graffowi, od roku 1766 zatrudnionym w drezdeńskiej Akademii Sztuk Pięknych ${ }^{2}$. To w ich prywatnej korespondencji w odniesieniu do masywów górskich majaczących na horyzoncie Drezna po raz pierwszy pojawiło się określenie „Szwajcaria tutejsza”, czyli Saksońska³ .

Podobnie jak w Alpach i Karkonoszach także w Górach Połabskich już na przełomie XVIII i XIX wieku zaczął się rozwijać międzynarodowy ruch turystyczny. Do wzrostu jego popularności przyczyniły się pierwsze kompleksowe opisy nieprzetartych jeszcze wówczas szlaków i atrakcyjnych obiektów Saskiej Szwajcarii - pełniące funkcję przewodników, jako że zawierały wiele cennych informacji o tym subregionie, jego walorach przyrodniczo-krajobrazowych, historii i kulturze - autorstwa Karla Heinricha Nikolai, Wegweiser durch die Sächsische Schweiz (1801) oraz Wilhelma Leberechta Götzingera Schandau und seine Umgebungen oder Beschreibung der sogenannten Sächsischen Schweiz (Bautzen 1804) (w drugim wydaniu opis ten został wzbogacony o szczegółową mapę Schandau und seine Umgebungen oder Beschreibung der sogenannten Sächsischen Schweiz mit Topo- und Petrographische Reisekarte durch die Sächsische Schweiz und

1 Saska Szwajcaria — nazwa geograficzna; określenie w tytule „Szwajcaria Saska” jest nazwą zwyczajową stosowaną powszechnie w XIX wieku.

2 https://www.saechsische-schweiz.de/malerweg/wanderweg-malerweg/geschichte.html (dostęp: 30.01.2019).

3 https://www.saechsische-schweiz-tipp.de/geschichte-tourismus.html (dostęp: 30.01.2019); W. Keiser, Od Rugii do Saskiej Szwajcarii, Warszawa 1989, s. 148-153; https:/de.wikipedia.org/ wiki/S\%C3\%A4chsische_Schweiz (dostęp: 30.01.2019); S. Liebe, L. Kempe, Sächsische Schweiz und Ausflüge in die Böhmische Schweiz, Leipzig 1974, s. 5. 


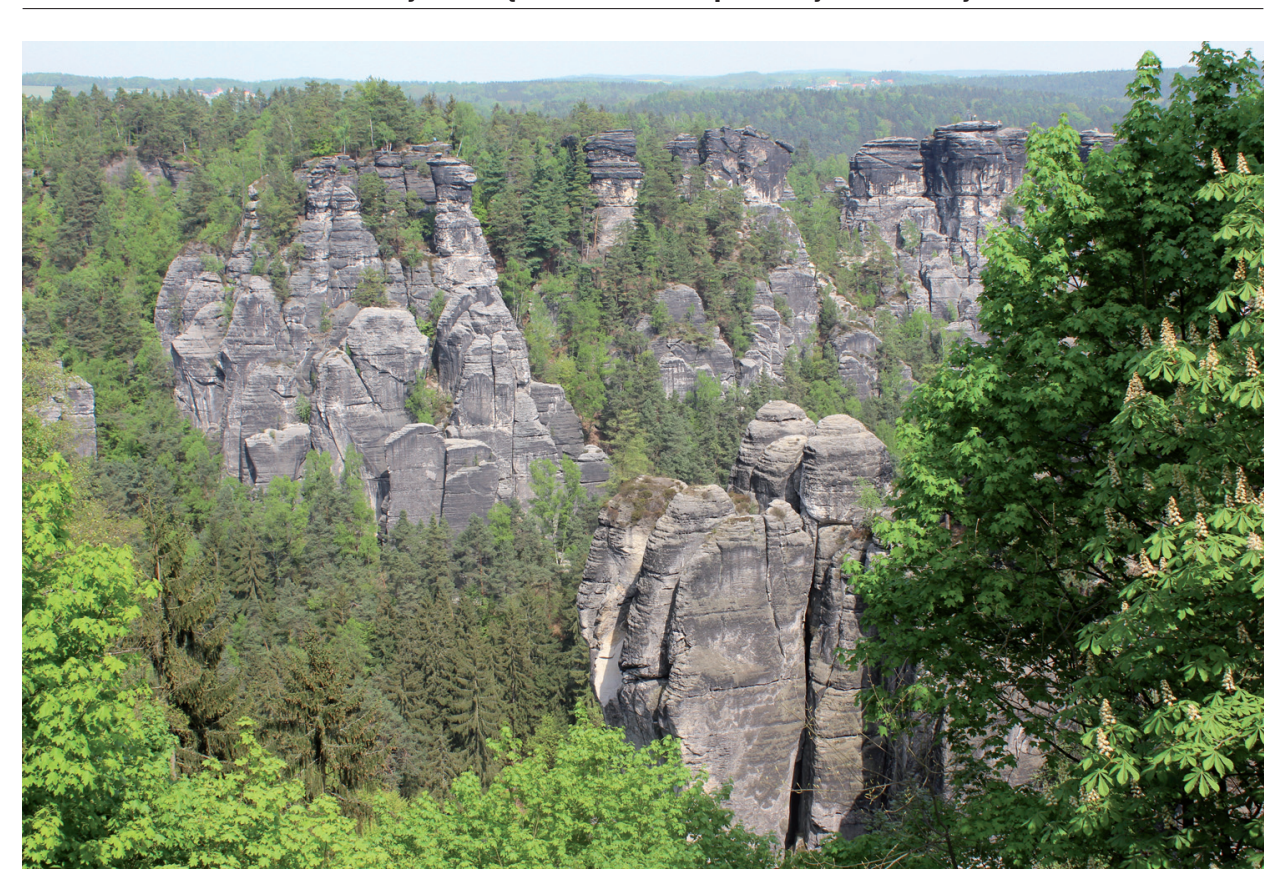

1. Skały Bastei, fot. Ewa Grzęda (2018)

umliegende Gegend, Dresden 1812). Zarówno Nikolai, jak i Götzinger posługiwali się już nazwą Saska Szwajcaria, przyczyniając się w ten sposób do jej ostatecznego utrwalenia i spopularyzowania. Warto nadmienić, że obaj byli reprezentantami saksońskich elit intelektualnych i zostali uznani za odkrywców oraz pierwszych propagatorów Saskiej Szwajcarii jako atrakcyjnego regionu turystycznego.

Nikolai był z wykształcenia teologiem, zajmował się literaturą, uczył religii i geografii. Jako mieszkaniec Lohmen - miejscowości, w której na początku XIX wieku rozpoczynał się szlak wycieczkowy po Saskiej Szwajcarii — był jednym z pierwszych przewodników po okolicy. Ówcześni turyści najchętniej zwiedzali Saską Szwajcarię z przewodnikiem, którego najczęściej wynajmowali właśnie w Lohmen. Pomiędzy rokiem 1804 i 1812 liczba turystów odwiedzających owe góry wzrosła do tego stopnia, że w 1812 roku w pobliżu jednej z największych atrakcji turystycznych — grupy skalnej nad Łabą, zwanej Bastei (okolice Rathen), przez polskich turystów nazywanej czasem Basteją lub Basztą — pojawiły się zalążki infrastruktury aprowizacyjno-turystycznej (sprzedawano tam żywność, a w najbliższej okolicy powstawały obiekty noclegowe).

W pierwszym dziesięcioleciu XIX wieku malownicze krajobrazy Gór Połabskich, a dokładniej niezwykłość tamtejszej pierwotnej przyrody, zaczęły silnie inspirować wyobraźnię drezdeńskich malarzy. W 1808 (1809?) roku powstał jeden z najsłynniejszych wczesnoromantycznych obrazów ołtarzowych autorstwa Caspara Davida Friedricha Kreuz im Gebirge, znany także jako Tetschener Altar, gdyż przez pewien czas pozostawał w rękach księżnej Thun-Hohenstein, rezydu- 
jącej na zamku w Tetschen (czes. Děčín). Friedrich w sposób bezprecedensowy i zapowiadający wielki przełom romantyczny w malarstwie sakralnym wykorzystał lokalny krajobraz, ukazując skały i lasy Saskiej Szwajcarii w konwencji hierofanicznej. Do dzisiaj jest to jeden z najsłynniejszych i najlepiej rozpoznawalnych, obok słynnego Wędrowca w górach, obraz tego malarza.

Saska Szwajcaria - jako region o wyjątkowej atrakcyjności turystycznej, położona w Europie Środkowej, a zatem nieledwie przylegająca do ziem polskich bardzo szybko zaczęła przyciągać przybyszów z Polski, przemierzających Europę w celach turystycznych, a po klęsce powstania listopadowego poszukujących na terenie Saksonii azylu politycznego. Wydaje się, że zanim Polacy dotarli w Alpy i na dobre odkryli rodzime Tatry, uczyli się pieszych wędrówek po górach w Karkonoszach i równocześnie także w Saskiej Szwajcarii.

Pierwszą dobrze udokumentowaną polską relacją z dwudniowej peregrynacji po Saskiej Szwajcarii, odbytej w 1825 roku, jest literacki debiut Andrzeja Edwarda Koźmiana (syna Kajetana Koźmiana) pod tytułem Dwa dni w Szwajcarii Saskiej. Podobnie jak saksońskich autorów pierwszych opisów Sächsische Schweiz Koźmiana wyróżniało staranne wykształcenie akademickie, mające niewątpliwie wpływ na rozwój jego osobowości i erudycji. W 1824 roku ukończył on Wydział Administracji na Uniwersytecie Warszawskim i rok później wyruszył na swoją pierwszą wycieczkę zagraniczną do Niemiec. Zatrzymał się na dłużej w Dreźnie, ale zwiedził też Wrocław i Berlin oraz odbył dwudniową wędrówkę po Saskiej Szwajcarii. Trzy lata później, w roku 1828, opublikował w Puławach wspomniany szkic. W pamiętnikach spisanych po latach zauważył, że podczas młodzieńczego pobytu w Saksonii nie mógł nie wybrać się na wycieczkę w tamtejsze góry, o których tak wiele słyszał. Owa konstatacja wydaje się istotna, gdyż wskazuje na skalę powszechnego już wówczas zainteresowania turystyką górską w jej wymiarze popularno-rekreacyjnym na terenie Europy Środkowej i dobrze już ugruntowaną pozycję Saskiej Szwajcarii w dziewiętnastowiecznym kanonie najatrakcyjniejszych turystycznie europejskich obszarów górskich. Z kolei ów pierwszy polski opis pieszej wędrówki po Saskiej Szwajcarii potwierdza tezę o związkach między literalnym podróżowaniem a aktywnością twórczą, zwłaszcza literacką ${ }^{4}$. Jest także dowodem na wyraźne wpływy tradycji i kultury anglosaskiej na kształtowanie się środkowoeuropejskiego modelu podróżowania i nowoczesnej, silnie zabarwionej filozofią romantyczną, wrażliwości na naturę i przestrzeń. Nie przypadkiem na karcie tytułowej Dwóch dni w Szwajcarii Saskiej znalazło się motto zaczerpnięte z II Pieśni Wędrówek Childe Harolda George’a Gordona Byrona, które w przekładzie na język polski brzmi następująco: „Rozmawiać z przyrodzeniem, i wpatrywać się w jego skarby rozpostarte".

Opisana przez Koźmiana wyprawa do Saskiej Szwajcarii w jakimś stopniu miała wymiar eksploracyjny - jednym z jej celów stał się bezpośredni, kompleksowo oddziałujący na organizm, umysł i wyobraźnię, kontakt z naturą, pozwala-

4 A. Irving, Podróże dalekie i bliskie. Roz-czarowanie percepcja, wiedza i ciałem, przeł. S. Sikora, „Teksty Drugie” 2018, nr 1, s. 173-199. 


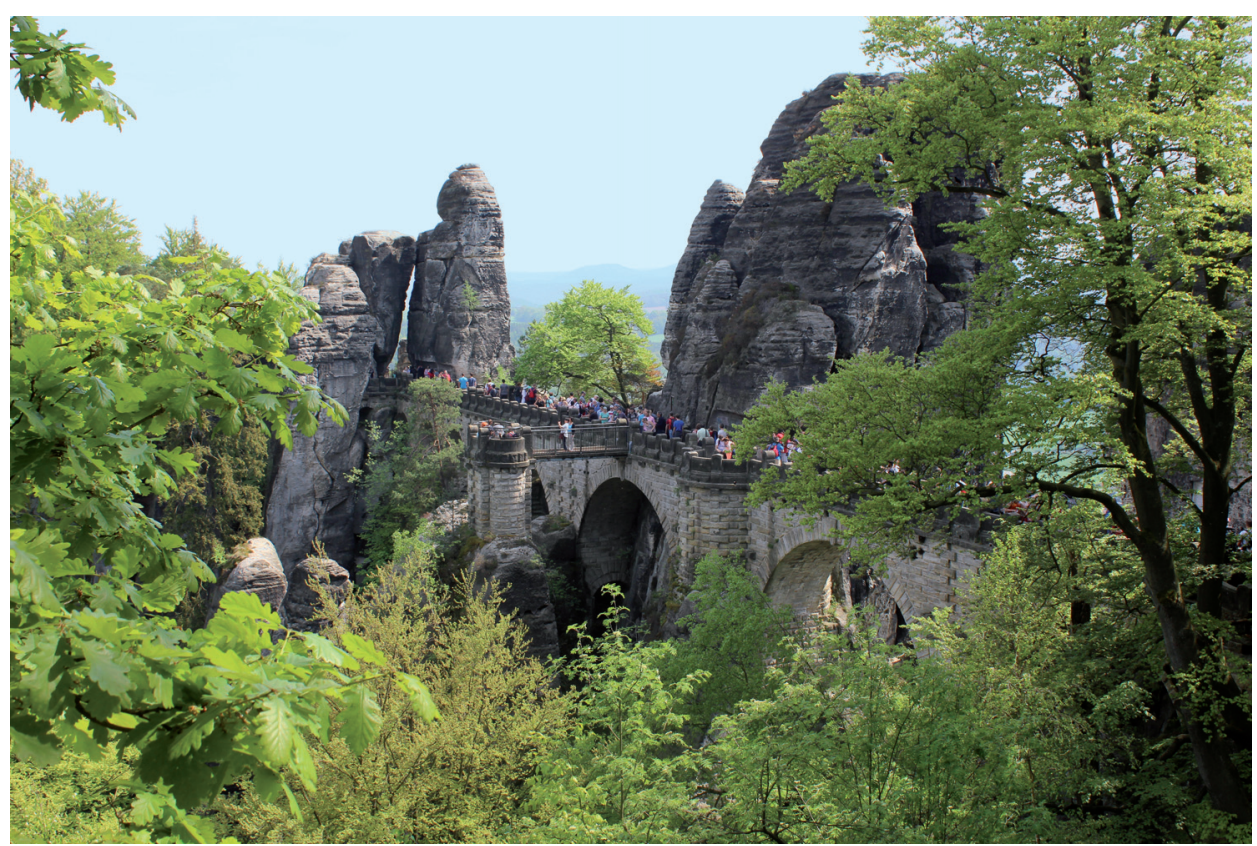

2. Kamienny most w Bastei, fot. Ewa Grzęda (2018)

jący młodemu podróżnikowi na przeżycie nieznanych dotąd wzruszeń stanowiących impuls do ich literackiego wyrażenia, co w wielu podobnych przypadkach urastało w tym czasie do rangi „metafizycznej konieczności”. Zasygnalizowana we wstępie, a następnie konsekwentnie determinująca sposób prowadzenia narracji postawa Koźmiana wobec piękna natury zdaje się antycypować także późniejsze koncepcje Johna Ruskina. Koźmian pisze na przykład:

Nie ma sądzę na ziemi całej człowieka, tak zimnego, lub tak zepsutego, który by zupełnie był nieczuły, na piękności przyrodzenia. Bo ze wszystkich rozkoszy, które osłodzić mogą chwile życia naszego, ta którą nas piękność natury napawa, jest najczystsza, a może najprawdziwsza, dla serca nieskażonego: ona zawsze nam przystoi, czy dusza nasza znajduje się w stanie radości, czy smutku, w tym nawet smutku, w którym pocieszenie każde, nie ulgą lecz ciężarem, każda przyjemność goryczą, w tym nawet, ta jedna tylko rozkosz, łagodzi duszy naszej boleść. I takiego to rodzaju uczuć szukać, o takie się starać, jest równie zgodne z dostojnością, jak z dobrem człowieka. Szukałem ich, znalazłem, i przez dwa dni doznawałem, a doznawszy, komuż się mam ich zwierzyć, jeżeli nie tobie. Kto nie był w tej okolicy, którą Szwajcarią Saską nazywają, będąc w Saksonii, ten nie widział tego, co najbardziej widzenia było godnem ${ }^{5}$.

\footnotetext{
5 A.E. Koźmian, Do Przyjaciela, [w:] idem, Dwa dni w Szwajcarii Saskiej, Warszawa 1828,
} s. $3-4$. 
W tym quasi-ideowym manifeście piękno natury zostało wyraźnie przeciwstawione wytworom cywilizacji, sama zaś natura postrzegana jest jako rodzaj tekstu, a kontakt z nią jako inwariant lektury. Kładąc zatem silny akcent na estetyczno-filozoficzny wymiar wędrówki po malowniczych okolicach, Koźmian dostrzega konieczność świadomego i starannego doboru towarzysza podróży, który powinien w podobny sposób reagować na piękno przyrody. Twierdzi arbitralnie, że w razie niemożności znalezienia odpowiedniego partnera lepiej wybrać się w taką podróż samemu. Ostatecznie wędrówkę po Saskiej Szwajcarii Koźmian odbył w towarzystwie Kazimierza Trembickiego - adiutanta wielkiego księcia Konstantego ${ }^{6}$. Wydaje się, że anonimowym adresatem zarówno wstępu, jak i całej relacji z wyprawy (Koźmian zwraca się do niego w tekście kilkakrotnie, ukrywając jego dane personalne) jest natomiast „podobnie czujący” Fryderyk Chopin, z którym autor przyjaźnił się od dzieciństwa.

Pierwszy etap podróży opisanej przez Koźmiana standardowo prowadzi z Drezna do Lohmen, choć za granice Saskiej Szwajcarii autor przyjmuje okolice Pillnitz — letniej rezydencji saksońskiej rodziny królewskiej. Oprócz refleksji na temat walorów tak martwej, jak i ożywionej przyrody i urozmaiconego malowniczymi grupami skalnymi krajobrazu relacja Koźmiana zawiera liczne uwagi o charakterze dokumentacyjnym, dotyczące na przykład rozmaitych realiów rozwijającej się wówczas turystyki górskiej oraz początków infrastruktury turystycznej na tym terenie. W tym kontekście istotna jest informacja, że wędrówkę po Saskiej Szwajcarii autor odbył pod opieką wynajętego w Lohmen przewodnika — Jana Stanfussa, z pochodzenia włościanina, wyróżniającego się wysoką kulturą osobistą i specyficzną świadomością polityczną oraz sporą, umiejętnie wykorzystywaną w trakcie oprowadzania po okolicy, wiedzą z zakresu lokalnej mikrohistorii ${ }^{7}$. W narracji Koźmiana pojawiają się także uwagi odnoszące się do poziomu rozwoju cywilizacyjnego społeczeństwa saskiego, konstatujące jego zaradność, przezorność i dobrą organizację życia ${ }^{8}$.

Dużą część relacji zajmują opisy doznań i wrażeń będących efektem kontemplacji krajobrazu podziwianego podczas pieszej wędrówki. Wielokrotnie przedmiotem literackiej deskrypcji obok samego krajobrazu stają się ekstatyczne doznania wywoływane przez rozmaite bodźce sensualne, przede wszystkim wzrokowe. Moment konfrontacji z pierwszymi grupami skalnymi Koźmian opisuje, nie unikając charakterystycznego dla całego tekstu tonu egzaltacji:

Lecz wkrótce doszliśmy do wioski otoczonej ciemnymi świerkowymi lasami; tu się zaczyna prawdziwa Szwajcaria Saska, zawołał nasz przewodnik, tu w ten parów wejdziemy, tu jest Ottowalder Grund. - Schodząc w dolinę, czyli raczej w przepaść po 114 schodach, czekaliśmy z niecierpliwością na ten widok, który nam miał Szwajcarię Saską objawić. -

6 A.E. Koźmian, Wspomnienia, t. 1. Pamiętniki z dziewiętnastego wieku, Poznań 1867, s. 396.

7 E. Domańska, Mikrohistorie. Spotkania w międzyświatach, Poznań 1999, s. 236.

8 A.E. Koźmian, Dwa dni..., s. 10. 
Zeszliśmy na koniec, a z obydwu stron, uderzyły nas obrazy wspaniałe, do których oko nasze przyzwyczajonym nie było; — z zadziwieniem spoglądaliśmy na nie, i na siebie, bo pierwsze wrażenie jest najmocniejszym. - Skały ogromne okryte jodłami i świerkami, z jednej i drugiej strony doliny, kształt ich rozmaity, kolor czerwonawy, nieznajome oku naszemu, przedstawiają widoki, nieznajome budziły w nas uczucia. Zdawało nam się, żeśmy nowy świat znaleźli, że przeniesieni jesteśmy, w piękną krainę ułudy ${ }^{9}$.

Ta silna, granicząca z „olśnieniem”, reakcja na otwierający się przed wędrowcami górski krajobraz jest doświadczeniem powtarzającym się u odkrywców i pionierów eksplorujących dzikie obszary górskie ${ }^{10}$. Koźmian wędrujący po Saskiej Szwajcarii w 1825 roku nie był pierwszym polskim turystą w Górach Połabskich - Polacy, czego dowodzą wpisy do ksiąg pamiątkowych wystawianych w tym regionie przy atrakcyjnych obiektach turystycznych, odbywali wędrówki po Saskiej Szwajcarii przed Koźmianem. Do 1828 roku nie powstał jednak żaden spektakularny polski opis podróży po tych górach. Nie ulega wątpliwości, że młodziutki Koźmian, pisząc relację z dwudniowej wycieczki, stał się ich odkrywcą dla literatury i kultury polskiej. Choć nie był zdeklarowanym romantykiem, to jego młodzieńcza, spontaniczna reakcja na nowy typ piękna dostrzeżonego w skalistym i nieregularnym krajobrazie górskim, gdzie w strzelistości form w szczególny sposób uobecnia się wzniosłość ${ }^{11}$, wykazuje szereg konwergencji z wrażliwością romantyków świadomie reagujących na walory nieregularnych tworów dzikiej przyrody. Co ważne i godne odnotowania, w opisie Koźmiana pojawiają się stylizacje typowe dla romantycznej poetyki podróży. W tym ujęciu podróż przebiegająca w literalnej przestrzeni topograficznej równolegle staje się podróżą metafizyczną i podróżą „,w głąb siebie”. W związku z tym kolejne fragmenty literackiego opisu wędrówki kształtują się na wzór palimpsestu. Wrażenia zmysłowe, będące pochodną bezpośredniej recepcji przestrzeni fizycznej, zostają uzupełnione przez grę erudycji, wyobraźni i „wzroku wewnętrznego”. Skalista, nieregularna przestrzeń zaczyna pełnić funkcję sceny, na której pojawiają się fantomy postaci historycznych, a wśród strzelistych skał ulokowany zostaje panteon europejskich poetów klasycznych i romantycznych.

Obok stylizacji na modłę romantyczną w narracji Koźmiana od czasu do czasu pojawiają się także tendencje racjonalistyczne, czego dowodzą jego reakcje

9 Ibidem, s. 12.

10 S. Ismer, N. Peter, „Das alles ist Teil einer Reise zu sich selbst” - Grenzerfahrungen als identitätsstiftendes Moment in zeitgenössischen Autobiographien von Bergsteiger *innen / „To wszystko jest częścia podróży do samego siebie” — doświadczenia graniczne jako moment ksztattujący tożsamość we współczesnych autobiografiach wspinaczy, „Góry - Literatura - Kultura” 11, 2017, s. 377-397.

11 Zob. np. K. Stibral, Co štětec nezachytí? Vztah krajiny a jejího zobrazení v rámi teorie malebna, [w:] Krajina - maska prírody? Studie k estetice krajiny a environmentu, red. K. Stibral, V. Faktorová, České Budějovice 2015, s. 77-102. 
na baśniową etymologię lokalnych, powszechnie stosowanych nazw efektownych formacji skalnych:

Przeszedłszy przez bramę, którą ogromnej wielkości głazy z sobą spojone tworzą, pokazał nam nasz przewodnik, kuchnię, piec, i ambonę czarta, tak są nazwane, rozmaite wydrążenia w skałach, tworzące otwory, przez które przechodzić można. - Wyobrażenia o czartach, upiorach, złych duchach, tam są powszechne, gdzie przyrodzenie, dzikie, przerażające, przedstawia widoki, i dlatego w Ottowalde Grund, zły duch ma swój piec, swoją kuchnię, swoją ambonę. — Łatwo jest więc pojąć, czemu prawie wszystkie powieści w Szkocji i w Niemczech, pełne są podobnych wyobrażeń, lecz byłoby śmiesznością, gdybyśmy je sobie przyswajać chcieli, i piaski Mazowsza, bagna Polesia, lub bory Litwy zaludniali, tymi utworami dzikiej wyobraźni, którą tylko wielkie i przerażające obrazy obudzić mogą ${ }^{12}$.

Owa konstatacja w świetle współczesnych badań nad estetyką krajobrazu górskiego i kategorią wzniosłości wybrzmiewa nowocześnie. Koźmian wykazuje tu dobrą intuicję, dostrzegając związki pomiędzy pewnego typu nieregularnymi i strzelistymi tworami natury a typem wyobraźni literackiej i twórczej ${ }^{13}$.

Pierwszy etap wędrówki Koźmiana w myśl sugestii i wskazówek pierwszych niemieckich opisów Saskiej Szwajcarii prowadzi do słynnej już wówczas Bastei. Architektura tamtejszych grup skalnych oraz widok rozciągający się z usytuowanej wysoko nad korytem Łaby platformy widokowej wywołał w psychice młodzieńca odczucia graniczne, w pewnym stopniu porównywalne ze stanem $f l o w^{14}$. Próbie ich literackiego opisu nie przypadkiem patronuje motto zaczerpnięte z $\mathrm{Po}$ dróży sentymentalnej Laurence'a Sterne'a: „I takich uczuć, niepodobnych do opisania doznałem, iż jestem przekonany, że one pochodzić nie mogły, ze związku ruchu z materią"15. Z kolei sam Koźmian, rekonstruując własne wrażenia z pobytu na skałach Bastei, pisze: „Gdym się zbliżył, na brzeg skały, z której cały widok Bastei rozwinął się przed nami, podobnież głos uniesienia, mimowolnie wydałem, a potem okiem zadziwionym w koło siebie prowadząc, stałem przez chwilę oniemiały"16. Analizując w dalszym toku relacji całą paletę uczuć uwolnionych w trakcie bezpośredniego sensualnego kontaktu z naturą górską i górskim krajobrazem, autor zapamiętane doznania interpretował jako inwariant zarówno zmysłowej, jak i duchowej rozkoszy. Natomiast zaobserwowany wówczas stan umysłu określił jako „uniesienie moralne”, umożliwiające refleksję nad istotą natury i jej

12 A.E. Koźmian, Dwa dni..., s. 14.

13 K. Stibral, Hory a divočina jako nový ideál krajiny. K proměně estetické hodnoty hor v 18. století, referat wygłoszony na konferencji z cyklu „Góry - Literatura - Kultura”, Idealizacja gór: przyroda, człowiek, kultura, Polanica-Zdrój 7-9 listopada 2018, maszynopis udostępniony przez autora.

${ }^{14}$ S. Ismer, N. Peter, op. cit., s 397.

15 A.E. Koźmian, Dwa dni..., s. 15.

${ }^{16}$ Ibidem. 


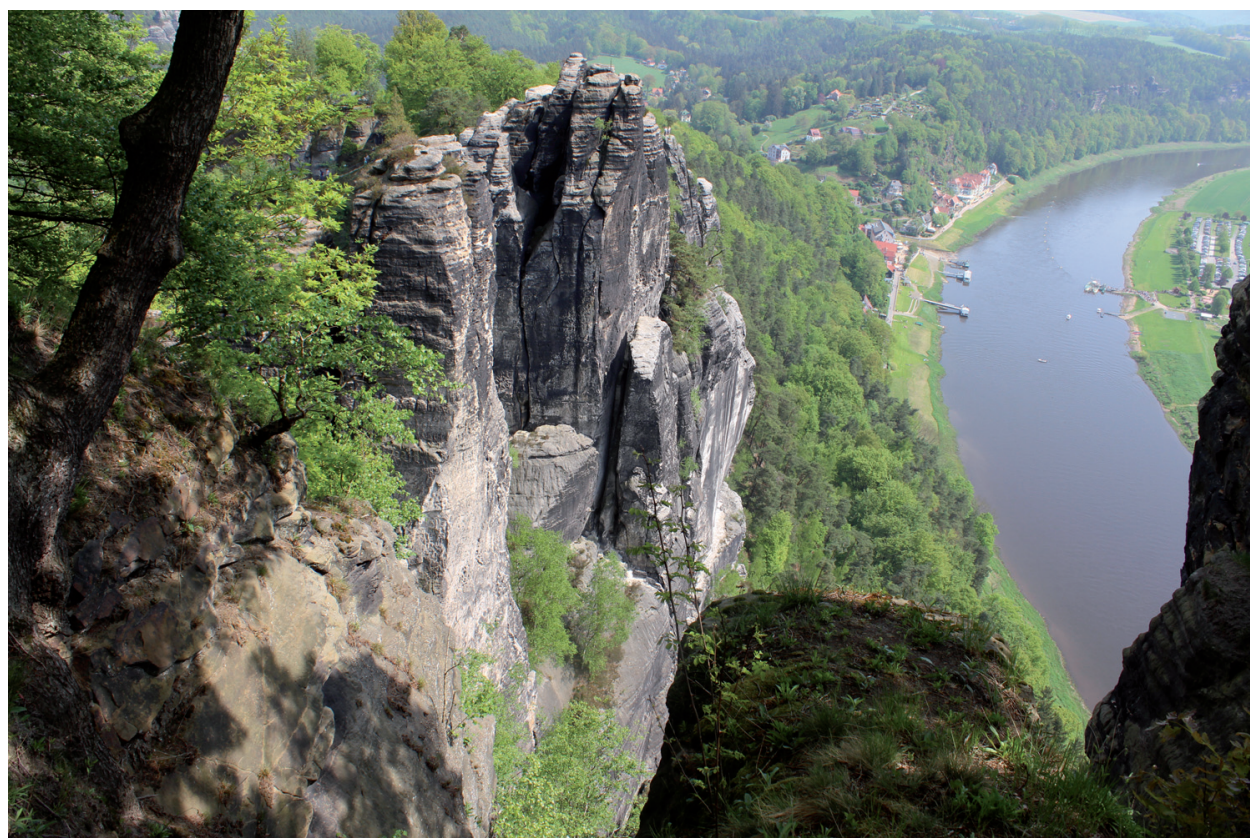

3. Koryto Łaby, fot. Ewa Grzęda (2018)

stwórcy. Równolegle racjonalnej analizie poddawał topograficzne szczegóły krajobrazu rozpościerającego się z górnych pięter Bastei. W tej perspektywie zwrócił uwagę na przełom Łaby i na rozległym horyzoncie dostrzegł położony na wyniosłej skale zamek Hohnstein, masyw Kaiserkrone, skały Lilienstein i warowną twierdzę Königstein, a także widoczne w oddali pasmo gór rozciągających się już na terytorium Czech.

Wśród szczegółów odnoszących się do stylu wędrówki podawał także trywialne informacje o obiedzie zjedzonym w pobliżu Bastei w namiotach stanowiących zaczątek lokalnej infrastruktury turystycznej oraz pojeździe, w którym pokonał niewielki odcinek drogi przed kontynuacją pieszej wycieczki w kierunku Hohnstein. Z osobliwości zwiedzanych w okolicach Hohnstein wymienił między innymi Teufelbrücke, o którym pisał, że jest to: „,most szatański, tak nazwany, iż przepaść nad którą jest zarzucony, może choć w części przypominać tę, nad którą ów słynny most w Szwajcarii jest zarzucony"17. Przytoczony komentarz wydaje się tym bardziej znamienny, iż Koźmian w Szwajcarii nigdy nie był. Erudycyjne porównanie kontemplowanego krajobrazu ze słynnym obiektem alpejskim jest wyraźnym potwierdzeniem utrwalania i zakorzenienia w zbiorowej świadomości kanonu atrakcyjnych obiektów alpejskich.

Ciekawie wybrzmiewają również fragmenty relacji opisujące nagłe załamanie pogody. Obserwacja krajobrazu w tych nowych okolicznościach, w odmiennym

17 Ibidem, s. 23. 
oświetleniu, radykalnie wpływającym na kolorystykę dominującej palety barw, okazuje się dodatkowym silnym przeżyciem o zabarwieniu nieledwie przygodowym. Koźmian pisze w związku z tym:

Będąc na górze wyniosłej, byliśmy wśród samej sceny burzy. Koło nas samych, pod nogami naszymi, tłumnie przesuwały się obłoki. Czułem, iż dusza moja była w tej chwili mocniejszą, bo też to powietrze w gniewie, silnie na duszę i na wyobraźnię moją działało. Nie wiem czy wszyscy tego, co ja doznają, lecz zawsze podczas i po burzy, czuję w sobie więcej siły tak fizycznej, jak moralnej; może przyczyna tego, jest bardzo prosta, jest to może skutkiem elektryczności, która równie na mnie, jak na istoty roślinne wywiera działanie ${ }^{18}$.

Wspomnienie burzowej atmosfery przekształcającej malowniczy pogodny pejzaż w krajobraz pełen ekspresjonistycznych kontrastów okazało się impulsem do rozważań nad konwencją literacką o charakterze autotematycznym:

Wtenczas uczułem, całą prawdziwość obrazów tych wieszczów, którzy wśród gór, skał i dolin zrodzeni, góry, skały i doliny śpiewali. Przypomnieli mi się szkoccy poeci, Ossyan na myśli stanął. — Obłoki, jakby para, ważące się długo nad doliną, wznoszące się powoli i na górach osiadające, oddalone grzmienie, i ta jeszcze jakaś niespokojność w naturze, chociaż już burza minęła, opisy barda Szkockiego przypominały. I chociaż podobnegom jeszcze nigdy obrazu nie widział, znałem go już, bom Ossyana czytał ${ }^{19}$.

Opisując zwiedzany w następnej kolejności zamek Hohnstein, Koźmian podaje błędną informację o uwięzieniu w nim hrabiny Anny Konstancji Cosel — w rzeczywistości była ona więziona i zmarła w saksońskiej twierdzy Stolpen. Opowiada także anegdotę o spotkaniu w drodze powrotnej wspinającego się w górę znanego w okolicy „pięćdziesięcioletniego starca" — byłego wojskowego, przemierzającego tę drogę każdego dnia w celu terapeutycznym, w poszukiwaniu na łonie górskiej przyrody „antidotum” na skołatane nerwy i dojmujące niepowodzenia losu. To spotkanie staje się dla Koźmiana impulsem do skonstruowania uogólniającej tezy o terapeutycznym oddziaływaniu na umysł ludzki malowniczego bądź wzniosłego krajobrazu:

Widok cudownych dzieł przyrodzenia, świeżość majowych poranków, wonie ziół i kwiatów, są jedynym balsamem dobroczynnym na niezgojone serca rany. - Uważajmy, że człowiek zdradzony od losu, albo od ludzi, człowiek, który wielkich nieszczęść doznał, lub ten który wszystkiego użył, i wszystkim jest znudzony, znosi jeszcze bez utęsknienia to

18 Ibidem, s. 26.

19 Ibidem, s. 27. 
życie, jeszcze w nim nawet przyjemności upatruje, jeżeli chcąc zapomnieć, swego smutnego doświadczenia, srogości losu lub gorszej od niej sytości, do natury się ucieka ${ }^{20}$.

Na zakończenie pierwszego dnia wędrówki młodzieniec oglądał wiejski cmentarz pod miasteczkiem Schandau (dzisiaj Bad Schandau). Koloryt tego miejsca przywiódł mu na myśl słynną lekturę pokoleniową Thomasa Graya Elegy Written in a Country Churchyard. Na noc zatrzymał się w Schandau, gdzie w tamtejszej oberży korzystał ze słynnych już wówczas mineralnych kąpieli.

Kolejny dzień Koźmian rozpoczął od zwiedzania widowiskowych, malowniczych skał Kuhstall, o których pisał następnie z właściwą sobie autentyczną egzaltacją:

Słowa żadne nie zdołają odmalować, sama nawet wyobraźnia z trudnością by mogła utworzyć, ten cud przyrodzenia. Bastei ani Brandu, żaden pędzel nie wyda, żaden przynajmniej tym nie zdoła napoić uczuciem, którym one przejmują, lecz prędzej malarz, zdołałby tę masę skał Kuhstalem nazwaną, rysunkiem oznaczyć 21 .

Naturalne twory skalne oglądane w Kuhstall autor porównuje do architektury gotyckiej:

W naturze, skały rozmaite mają kształty, jednak zawsze ogromne, straszne. - Zdawałoby się wręcz, iż architektura gotycka najbardziej do przyrodzonej zbliżona, jest pierwiastkową. Piramidy egipskie, dzieci sztuki niewydoskonalonej jeszcze, lecz najdawniejszym będące tejże sztuki pomnikiem, zbliżają się do pierwotnego, do przyrodzonego kształtu, do tego, który w skałach uważamy. Te piramidy, ileżby przemawiały do wyobraźni mojej, lecz ileż jest silniejszy głos tych tworów przyrodzenia, które wieki upielęgnowały ${ }^{22}$.

Istotne wydają się tu również informacje o kompetencjach przewodnika, który w konkretnych miejscach udzielał polskim turystom erudycyjnych informacji na temat fenomenów lokalnej tradycji. Tłumaczył na przykład etymologię nazwy Kuhstall i wspominał wydarzenia historyczne, które miały miejsce w najbliższej okolicy, w szczególności zwracał uwagę na charakterystyczne dla tych terenów konflikty religijne między husytami i katolikami.

W relacji ze zwiedzania tamtejszej jaskini Koźmian zamieścił także cenne informacje o naskalnych napisach pozostawionych tam przez licznie ją odwiedzających turystów. Zwyczaj rycia na atrakcyjnych obiektach turystycznych inskrypcji upamiętniających pobyt w tych miejscach był w pierwszej połowie XIX wieku bardzo powszechny. Ta zgoła niechlubna praktyka, dzisiaj postrzegana jako akt

\footnotetext{
20 Ibidem, s. 34.

21 Ibidem, s. 54.

22 Ibidem, s. 57.
} 
wandalizmu, paradoksalnie pozwala współczesnym historykom na rekonstrukcję frekwencji i stylu zachowań ówczesnych turystów ${ }^{23}$.

W tej jaskini, do której po drabinie się wchodzi, zbrodniarz jeden długo się ukrywał i bronił [...]. Obejrzawszy wszystkie części tej groty, wróciliśmy do niej; chociaż obszerna, cała jest zapisana imionami tych, którzy ją zwiedzali. Niektórzy nawet blachy z imionami swoimi poprzybijać kazali $^{24}$.

Komentując owo zjawisko z dużą dozą ironii, Koźmian nadmieniał równolegle o wystawionych w grocie dla zwiedzających dwóch księgach pamiątkowych:

Oprócz ścian tej skały, jest jeszcze dwie książek otwartych zawsze, dla chcących się w nich zapisać. Są one napełnione różnymi imionami, jako też różnymi spostrzeżeniami filozoficznymi, i wymownymi uwagami, o wielkości Boga, znikomości człowieka, o wschodzie słońca, o życiu pustelniczym ${ }^{25}$.

Na szlaku wędrówki Koźmiana znalazły się jeszcze wzgórza Kleiner Winterberg, gdzie można oglądać altanę upamiętniającą polującego w tych okolicach wówczas jeszcze elektora Augusta (późniejszego Augusta II Mocnego), oraz Grosser Winterberg. W komentarzu snutym wokół zwiedzania tych miejsc wiele spostrzeżeń dotyczy między innymi spotykanych na każdym kroku udogodnień dla mniej wytrawnych turystów, na przykład kutych w skałach schodów, mostków czy barierek, finansowanych przez samego króla Saksonii. Koźmian zachowywał jednak wobec nich dystans, opowiadając się za utrzymaniem krajobrazu w formie nietkniętej piętnem cywilizacji. W dalszej narracji obecne są także uwagi dotyczące strategii konstruowania literackiego opisu krajobrazu, zbliżone do dzisiejszej koncepcji ekfrazy. Wspominając swój pobyt na szczycie Wielkiej Zimowej Góry (Grosser Winterberg), autor pisał:

Wykrzyknienie jest zazwyczaj głosem, który nam uniesienie wyrywa, lecz jak najwyższy smutek, nie łza ale martwość cechuje, tak najwyższego stopnia uniesienia milczenie dowodzi! Zamilkliśmy gdyśmy się ujrzeli na samym wierzchołku zimowej góry, i dopiero gdy pierwsze przeminęło wrażenie, gdyśmy się przekonali, że nie złudzenie mamiło zmysły i duszę naszą, wydaliśmy głos uniesienia, — lecz jakże Ci to opisać, co wtenczas przed oczyma, a teraz jeszcze tak wyraźnie mam w myśli; jakbym na próżno starał się zrobić dokładny opis obrazu Rafaela, lub rzeźby

${ }^{23}$ K. Jaworski, Turystyka polska w czeskich Sudetach $w$ XVIII $i$ XIX wieku, „Góry - Literatura - Kultura" 3, 1998, s. 9-19.

24 A.E. Koźmian, Dwa dni..., s. 59.

25 Ibidem, s. 60. 
Kanowy, i wyrazami wydać czego się doznaje, patrząc na nie, tak bym nadaremnie się kusił dać ci wyobrażenie o obrazie, który w tej chwili rozpostarty był przed moim okiem ${ }^{26}$.

W procesie oswajania rozległego krajobrazu obserwowanego ze szczytu pojawiła się spontaniczna potrzeba jego uporządkowania. Wymowne jest tu porównanie owego widoku do mapy i próba przeprowadzenia orientacyjnej analizy topograficznej wyróżniających się w tej przestrzeni obiektów i punktów. Interesująco wybrzmiewa równoległa analiza własnych psychofizycznych doznań zapamiętanych z okresu górskiej wędrówki, wyraźnie zdominowanych przez skrajnie pozytywne emocje. Koźmian pisał w tym kontekście o rozkoszy i największym szczęściu. Zanotował również, że w domu gościnnym przeglądał kolejne księgi pamiątkowe. W tym fragmencie interesująca wydaje się przeprowadzona przez niego analiza konwencji umieszczanych tam wpisów, trafnie oceniająca model ich dystrybucji, w wielu wypadkach polegający na kopiowaniu i plagiatowaniu. Ciekawy dokument stanowi przytoczony in ecstenso jeden z odnalezionych wpisów polskojęzycznych:

Dusza moja rozkołysana wśród uniesień ku stwórcy, i myśli o znikomości i nicości człowieka, użyła słodkich rozkoszy wschodu słońca. Tutaj człowieku dumny, upokorz się, uwielbiaj twego stwórcę; poznaj nicość Twoją bo jesteś niczem. - Nocowałem na Winterbergu dn. 18 lipca, i życzę rodakom moim aby równie unoszących rozkoszy doznali ${ }^{27}$.

Po zejściu z Grosser Winterberg Koźmian podziwiał jeszcze skały Tempel, gdzie w majestatycznej i nastrojowej scenerii w okresie wzmożonego ruchu turystycznego starzec (ofiara wojny) podający się za czciciela natury w towarzystwie młodej dziewczyny zbierał jałmużnę, wykonując nastrojowe, dostosowane do charakteru otoczenia, pieśni przy wtórze harfy, co miało stanowić imitację tradycji osjanicznej. Tego typu zjawiska świadczące o przekształcaniu dzikich i nieucywilizowanych przestrzeni górskich w obszary turystyczne, stające się z wolna dochodowymi strefami ekonomicznymi, były w tym czasie powszechne. Przykładowo w Karkonoszach na szlaku na Śnieżkę masowo ustawiali się kataryniarze, którzy starali się za pomocą dźwięków katarynek urozmaicać monotonię wędrówki turystom, w życiu codziennym odwykłym od ciszy i samotności.

Ostatnim atrakcyjnym widokowo obiektem na trasie wędrówki Koźmiana była skalna brama Prebischthor, położona już na obszarze określanym dzisiaj jako Czeska Szwajcaria. Specyfika, kolorystyka krajobrazu rozciągającego się w jej otoczeniu po raz kolejny uruchomiła ujawniającą się już wcześniej romantyczną wrażliwość Koźmiana:

Góra Rosenberg jakby płaszczem zielonym okryta borem jodłowym, jak olbrzym jaki wznosi się wśród ciemnych gór czeskich. Za nią wygląda-

26 Ibidem, s. 65.

27 Ibidem, s. 68 . 
ją szczyty gór dalszych. — Jakiś przyjemny nieporządek, panuje w tym obrazie, zdaje się on być tworem bujającej wyobraźni, i jeśli więcej podobnych tworów przyrodzenia kraje niemieckie wystawują, nie dziwię się jeśli tam wyobraźnia tworzy romantyczne piękności ${ }^{28}$.

W opisie pojawiały się też uwagi dotyczące ekonomicznych aspektów turystyki. Koźmian zauważa na przykład, że za zejście po wyposażonych w poręcz schodach do górskiej chatki tym razem trzeba było wnieść opłatę, co wiązało się z przekroczeniem granicy i znalezieniem się na terenie Czech, gdzie obowiązywał inny porządek ekonomiczny. Droga powrotna prowadziła prosto do Schandau (ten odcinek został pokonany promem płynącym po Łabie), a następnie pojazdem konnym przez Königstein do Pirny i dalej z krótkim postojem w Sonnenstein — miejscu historycznego obozowiska króla Saksonii z okresu wojny siedmioletniej — do Drezna.

Oprócz relacji z podróży, wydanej w formie szkicu pod tytułem $D w a d n i$ w Szwajcarii Saskiej, wspomnienie owej młodzieńczej wędrówki znajduje się również w spisanych po latach pamiętnikach Koźmiana. Z perspektywy czasu zarówno wachlarz reakcji emocjonalnych na krajobraz Gór Połabskich, jak i sama próba ich literackiego opisu zostały poddane autokrytycznej weryfikacji, nie uległa natomiast zmianie opinia autora na temat walorów krajobrazowych i kulturowych Saskiej Szwajcarii. Warto wobec tego przytoczyć nieco obszerniejszy fragment owych wspomnień:

Zostając kilka tygodni w Dreźnie, jakże było nie zwiedzić Szwajcarii Saskiej, owej uroczej miniatury prawdziwej Szwajcarii, o której tyle słyszałem i która mogła dać wyobrażenie o naturze w całej sile i wspaniałości. Ułożyłem się z Kazimierzem Trembeckim, adiutantem W. księcia Konstantego a dzisiejszym senatorem, i puściliśmy się razem na dwudniową wędrówkę. Do Lohmen dojechaliśmy pojazdem, stamtąd pieszo przez dzień cały podróżowaliśmy, konie i pojazd odesławszy do Schandau. Byłem wtenczas młody, z wrażliwą wyobraźnią, z umysłem wrażeń łaknącym, byłem rozmiłowany w naturze. Dziecię płaszczyzn, gdym się ujrzał wśród gór, skał i przepaści, gdy nawykłemu do sielanki wiejskiej obrazy epicznej natury stanęły przed oczami, zdawało mi się, żem się przeniósł w krainę czarów, złudzenia; byłem upojony, oczarowany i mniemałem, że na piękniejsze i wspanialsze obrazy nigdzie się już przyrodzenie ani zdobyło ani zdobyć mogło. Gdybym dziś te same lasy, góry i skały zwiedzał, pewnie bym takich samych uniesień nie doznał, nie mniemałbym, że od widoków Szwajcarii Saskiej nie ma w świecie wspanialszych i godniejszych podziwu; ale wtenczas obrazy te były dla mnie nowością a młodość dwoiła ich piękność, ich przepych: olbrzymiały one odbite w zwierciadle młodzieńczej wyobraźni, która jest zwykle zwierciadłem wklęsłym to jest powiększającym. Przedmioty zewnętrzne, na-

28 Ibidem, s. 76 
tura działają bez wątpienia na człowieczą duszę, ale daleko silniejszy jest jej wpływ na naturę. Filozofowie starożytni nazywali człowieka małym światem wśród świata wielkiego [...]. To co nas dzisiaj zachwyca i unosi, może się stać nam jutro obojętnym. Tak ja w owym czasie mojej wiosny naturę Szwajcarii Saskiej niejako uidealizowałem i pod wpływem tych wrażeń opisałem moją dwudniową wędrówkę. Dziś czytając ten opis, przyznałbym zbytek uniesień młodzieńczych, przesadę w opowiadaniu, która to przesada nie była kłamstwem z mej strony, bom opisywał, jak czułem. Czemuż mam się wstydzić wyznać, że, gdym ten opis, później drukiem ogłoszony, wykończył, znajdując w nim odbicie moich uczuć i wrażeń, tak z niego byłem uradowany, żem marzył dla niego głośną sławę. Wyobrażałem sobie, że będzie czytany, ceniony przynajmniej jak Sentimental Journey Sterna, że nie jednego czytelnika zachwyci i rozczuli. Zwodnicze marzenia niedoświadczonej młodości! Moje pisemko przeszło niepostrzeżone, mało, to jest tyle, ile było warte, cenione, a ja, gdym je dziś odczytał, uśmiechnąłbym się, żem był kiedyś tak młody ${ }^{29}$.

W kolejnych fragmentach pamiętnika Koźmian ponownie, tym razem w ujęciu syntetycznym, zrekonstruował trasę odbytej przed laty wędrówki i sformułował konkluzję zbliżoną stylistycznie w wymowie i konwencji do tekstu reklamowego:

Pierwszego dnia wśród wędrówki naszej zwiedziliśmy uroczą Basteję, Hochenstein, Hohnstein i Brand. Przenocowawszy w Schandau, gdzie są kąpiele żelazne i sławny połów pstrągów, dnia następnego ze świtem puściliśmy się pieszo na Kuhstall, na Winterberg, Tempesfall i Prebischtohr. Elbą wróciliśmy do Schandau, skąd pojazdem do Drezna. Opisawszy raz piękność i rozmaitość tych wszystkich widoków, nie będę się tu powtarzał. Radzę każdemu aby odbył tę wędrówkę, jeżeli ma nogi zdrowe i jeśli chce poznać urok gór i dolin, wspaniałości przyrodzonej architektury skał, przepych i bogactwo rozległych krajobrazów. Szwajcaria Saska nie wyrównywa potędze alpejskiej natury, góry jej są tylko pagórkami, brakuje jej jezior, wodospadów, lawin i wiecznych lodów. Jest to tylko szkic prawdziwej Szwajcarii, ale szkic tu wdzięczny, tam uroczy, dalej nawet wspaniały, a wszędzie miłe i silne wywołujący wrażenie ${ }^{30}$.

Trzy lata po wędrówce Koźmiana, dokładnie 12 września 1828 roku, krótką wycieczkę po wybranych fragmentach Saskiej Szwajcarii odbył Stanisław Deszert — radca stanu w Królestwie Polskim, który zatrzymał się na kilka dni w Dreźnie w początkowej fazie swojej podróży po Europie. W dzienniku pozostającym do dzisiaj w rękopisie zanotował kilka ciekawych uwag na temat warunków podróżowania, szczegółów dotyczących przebytego szlaku oraz spotkanych

29 A.E. Koźmian, Wspomnienia..., s. 396-397.

30 Ibidem, s. 398-399. 
i podziwianych osobliwości natury, a także oglądanych po drodze pamiątek historycznych i fenomenów lokalnej kultury:

Przy pięknych warunkach wyjechaliśmy do znanej Szwajcarii Saskiej a mianowicie do Bastey, przez pracowicie uprawne równiny na lewym brzegu Elby położone, laski sosnowe i dwie piękne osady Türkewitz i Laubegast mogące w rzędzie naszych miasteczek obwodowych zająć miejsca, zbliżyliśmy się ku rzece samej, za którą na wznoszących się pagórkach i wzgórzach winnice królewskie są rozpołożone i przybrane gdzieniegdzie domkami miejskimi lub altanami. — Wygodny prom na dwóch łyżwach urządzony z zamykanym pomostem, gdzie osiem powozów wygodnie stanąć może i przez kanonierów królewskich kierowany, którzy nazwiska pasażerów notują, przyprowadził nas na prawy brzeg Elby do Pilnitz tuż nad rzeką położonego pomieszkania letniego Familii panującej. - Przez aleje weszliśmy do ogrodu w starożytne szpalery grabowe przybranego, dalej na dziedziniec, na którym po prawej i lewej ręce są dwa pałacyki jednostajne w guście chińskim, i tuż przy nich po obydwóch stronach małe pawilony korynckiego porządku, wprost zaś zamyka dalszy widok gmach przed dziewięciu laty wystawiony [...]. Z Pilnitz jadąc, winnice królewskie zdobią część okolicy, którą się jedzie aż do lasu sosnowego i sadzonego, za którym wzgórzyste zaczynają się położenia, ładny jest widok na zamek Sonnenstein na rozmaite góry, skały, co wszystko prawie w oka mgnieniu niknie bo droga wraca się nagle w dolinę gdzie wieś Lohmen leży. - Stąd wziąwszy przewodnika drogą wzgórzystą przybyliśmy do wsi Ottowalde, skąd pieszo udać się wypadało - odesłaliśmy więc powóz do Bastey, a sami to jest K[rzysztof] Cieszkowski i ja w towarzystwie przewodnika Niemca ścieżką przez ładną łąkę zapuściliśmy się w przykry i zaledwo przystępny parów leszczyną, brzozami, sosnowym drzewem i świerkami porosły, a za pomocą 114 schodów w krętym kierunku w skałach wykutych zeszliśmy w nizinę gdzie chłodniejsza nierównie temperatura jest dowodem głębokości tego miejsca. - W tym więc zacienionym parowie zaczyna się Ottowaldsgrund nazwisko tej części skał i okolicy nadane. Ścieżka wąska tuż przy mruczącym strumyku wydeptana, wiedzie przechodnia wśród wyniosłych skał drzewem i mchem okrytych, na których domysł ludzki rozmaite wyobrażenia sobie upatrując, do pojęcia swojego przyswaja i zastosowywa odwieczne dzieła natury, których równie jak ich Twórcę ani dokładnie pojąć ani też ocenić nie jest mu dozwolono. - W tym to prawie niedostępnym ustroniu w pośród niepożytych odłamów granitowych, pokazują skały, którym nadano imiona Löwenkopf, Fraukopf. Dalej rozwaliny w czasie trzęsienia ziemi utworzone miejsca, krzyżami oznaczone na pamiątkę ludzi, którzy tam poginęli, zlatując z wierzchołków gór niedojrzanych. - Thor Ottowaldsgrund, Wahlfischkopf wszystko skały, a w bliskości tej ostatniej jest szczupła chatka, w której żona 
przewodnika naszego nazwiskiem Basch [?] przebywa latem i skromny posiłek za małą nagrodą przychodzącym przedaje ${ }^{31}$.

Deszert rozpoczął zatem swoją wycieczkę po Saskiej Szwajcarii w tym samym miejscu co Koźmian, lecz ze względu na jej wariant jednodniowy dotarł tylko do wybranych obiektów. Udało mu się zwiedzić Bastei - jeden z najsławniejszych i najciekawszych kompleksów skalnych, co także dla niego okazało się wyjątkowym przeżyciem i poruszającym doznaniem estetycznym. Rekonstruując w dzienniku szczegóły rozległej panoramy widocznej z platformy widokowej w Bastei, pisał:

- Cała ta okolica zawiera nieprzeliczone pasmo zdumiewających dzieł przyrodzenia, które na przemian trwogą lub podziwieniem umysł napawają, jakieś nieznane obudzają uczucia, a rozmaitością powabną, bawią oko ludzkie. - Wzgórzystym położeniem postępując doszliśmy do rozłożystego drzewa gdzie jest stół kamienny Steinernetafel, pamiętny z tego, że August II jadał na nim śniadanie roku 1710. - Monarchę tego w Saksonii zowią, a raczej dają mu przydomek der Starke. $-\mathrm{Z}$ miejsca tego brzegiem lasu wśród parowów głębokich położonego wyszliśmy na drogę wiodącą ku Bastey. Tam więc znaleźliśmy ładny dom altanami przyozdobiony, które w pośród drzew sosnowych urządzono. - W tym miejscu niespodziewanie i w oka mgnieniu wchodzi się na urwisko skały kratą żelazną obwarowanej, skąd widok jest zachwycający. — Po lewej ręce sterczą najeżone skały, między którymi przed wiekami najezdnicy łupy zebrane przechowywali, dalej zaledwo okiem dosięgnięte góry Czeskie: Rumberg, Scheeberg, Satelberg, bliżej zaś położone i do Saksonii należące Lauche, Basenberg, Königskrau, Cyrkielstein, Lilienstein, Staffenstein i Königstein na koniec Bärenstein i Jungferspnizeg góra sławna smutną pamiątką zgonu niewiasty, która chroniąc się od rozhukanego żołnierstwa szwedzkiego w przepaść się rzuciła w roku 1639, jak to miejscowe podanie niesie. - Za nimi w prawą rękę nieprzejrzane błonia i wzgórki pięknymi zaludnione osadami, u stóp zaś Bastey Elba wśród rozkosznych włości łąk i niw urodzajnych, krętym płynie korytem, ożywia i przyozdabia ten bogaty obraz utworów natury. — Z Bastey poszliśmy po schodach i przez mostki lub przejścia oparte na skałach do rozwalin gdzie niegdyś najezdnicy przytułek swój mieli, jedno z tych miejsc zowie się Thor Räuber, drugie dalej położone Kanape ${ }^{32}$.

W konkluzji Deszert odnosił się też z aprobatą do rozpowszechnionej i utrwalonej w pierwszej połowie XIX wieku nazwy Szwajcaria Saska:

31 S. Deszert, Dziennik podróży odbytej w latach 1828 i 29 przez S.D., rękopis Biblioteki Zakładu Narodowego im. Ossolińskich, sygn. II 3585, s. 25-27.

32 Ibidem, s. 27-28. 
Nie można dosyć nasycić oka w tym miejscu tak wszystko piękne tak powabne, i tyle jest zadziwiające. - Słusznie tej okolicy nadano nazwisko Szwajcarii Saskiej, bo mniemam, że mało jest krajów, gdzieby można znaleźć tyle urozmaiconych piękności natury, mogących podobieństwem swoim przypominać nadobną Helwetów krainę, którą da Bóg doczekać w powrocie moim zwiedzić nie omieszkam. - Zjadłszy w oberży na Bastey obiad niemiecki przy odgłosie muzyki, która przecie na moje wezwanie mazura nam zagrała, puściliśmy się dobrą drogą ku Lohmen, gdzie pokazywano nam wybór zawodu sławnego owiec z zakładów królewskich, skąd przez Pilnitz późnym mrokiem wróciliśmy do Drezna ${ }^{33}$.

Rok później na dwudniową wycieczkę po Saskiej Szwajcarii wyruszył także z Drezna Antoni Edward Odyniec, który w te okolice powrócił jeszcze w towarzystwie wybitnych polskich romantyków: Ignacego Domeyki, Stefana Garczyńskiego, Adama Mickiewicza i Wincentego Pola w 1832 roku $^{34}$.

We wspomnieniach nawiązujących do pierwszego pobytu w Sächsische Schweiz, pisanych w formie listu do Juliana Korsaka, podobnie jak inni literaci próbujący zmierzyć się z opisem górskiego krajobrazu Odyniec podjął temat trudności związanych z literackim przedstawieniem nie tylko majestatycznego piękna skał, lecz także wielu ekstatycznych uczuć pobudzonych przez sensualny kontakt z dziką przyrodą i nieregularnym górskim krajobrazem:

Gdybym miał czas i wenę po temu, w ,języku bogów" chyba mógłbym się kusić o zdanie Ci sprawy z wrażeń, jakie świeżo jeszcze tchną we mnie, po dwudniowym zwiedzaniu Szwajcarii Saskiej — istnej oazy skał i dzikiej natury, śród pól tak po niemiecku uprawnych, że żaden polny kwiatek nie ma gdzie sam dla siebie wyrosnąć. Ale chcieć opisywać to prozą, byłoby prawie to samo, co zasypywać piaskiem malowidło, albo opowiadać muzykę. A czuję w sobie jakby jedno i drugie: malownicze obrazy nagich skał, gór skalistych i lesistych wąwozów; a muzykę szumu drzew, strumieni i kaskad, która te skały i wąwozy ożywia. Ale przeczytaj te parę strof z pierwszej pieśni „Pani Jeziora” Waltera Scotta, w których jego bohater, zajeździwszy konia, drapie się pieszo przez jakiś tam wąwóz, nim się spotkał z Nimfą jeziora: a pewnie lepiej wyobrazisz sam sobie to właśnie, co ja widziałem, niż gdybym ci jak najtopograficzniej opisał i nazwał po imieniu wszystkie te bergi, sztejny i grundy, których zwiedzenie, widoki i przejścia, stanowią treść podróży po Szwajcarii Saskiej. Nie ma w niej wprawdzie jezior — a i nimf, niestety nie było; [...] Czechy — bo jestem już w Czechach (w piątym kraju od kwietnia) — o ile mogłem widzieć z gór Szwajcarii Saskiej, a potem dopływając Elbą do Teczen, kraj nie tylko równie żyzny i piękny jak Saksonia, ale bodaj nawet czy

33 Ibidem, s. 28.

34 A.E. Odyniec, Wspomnienia z przeszłości opowiadane Deotymie przez..., Warszawa 1884, s. $441-442$. 
nie piękniejszy; a przynajmniej tu, w tym punkcie, gdzie cudna dzikość gór i kamieni zlewa się i harmoniuje niejako z niemniej cudną bujnością zielonych nadelbiańskich dolin — jak np. fagoty i bębny ze skrzypcami i fletami w orkiestrze ${ }^{35}$.

Symptomatyczny jest także fakt, że Adam Mickiewicz, wspominając swój pobyt w Niemczech, za najcenniejsze doświadczenia z tego okresu — oprócz zawartej tam znajomości z Johannem Wolfgangiem Goethem i Augustem Wilhelmem Schleglem - uznawał „widzenie Szwajcarii Saskiej”36. Bardzo odległe, nieledwie fantomiczne wspomnienie Saskiej Szwajcarii pojawiło się również w opowiadaniu Wincentego Pola Wspomnienie podróży, opublikowanym w „Dzienniku Mód Paryskich"37.

W tym samym roku, w którym Saską Szwajcarię odwiedziło grono polskich poetów romantycznych przebywających w tym okresie w Dreźnie, wędrówkę utartym już szlakiem odbyła również Klementyna z Tańskich Hoffmanowa - autorka wydanego pośmiertnie opisu Drezno i jego okolice (1858). Hoffmanowa była pisarką i publicystką — pionierką polskiej literatury dla dzieci i młodzieży. Wiele jej książek adresowanych do młodego czytelnika miało formę zbioru listów bądź krótkich szkiców, których adresatką była jej dorastająca siostrzenica Helenka. Opis Drezna i jego okolic, zawierający relację z wędrówki po Saskiej Szwajcarii, został napisany w podobnej konwencji. W założeniu autorki miał pełnić poniekąd funkcję przewodnika przybliżającego polskiemu czytelnikowi — zwłaszcza młodemu - wiedzę o Saksonii, która poprzez historyczne unie personalne była silnie związana z Polską.

Krótka podróż po Saskiej Szwajcarii, rozpoczęta 9 lipca 1832 roku, wieńczyła półroczny pobyt Hoffmanowej w gościnnej Saksonii, którą musiała ostatecznie opuścić z przyczyn politycznych - w tym okresie pod naciskiem rządów Prus i Rosji z Saksonii wydalono dużą grupę Polaków szukających na jej terenie azylu po upadku powstania listopadowego. W tym gronie znalazła się także Hoffmanowa wraz z mężem — znanym historykiem; jako mieszkańcy Królestwa Polskiego już wcześniej byli inwigilowani przez władze rosyjskie ze względu na szeroką działalność patriotyczną.

Opisaną we wspomnianym szkicu wędrówkę po malowniczej górskiej okolicy rozciągającej się wzdłuż koryta Łaby Hoffmanowa rozpoczęła od krótkiego pobytu w Plauen, gdzie w tamtejszej oberży Crassa Villa spotkała Polaka przygotowującego posiłki dla turystów. Historyczne związki Polski i Saksonii stwarzały dogodne warunki do aktywności nie tylko politycznej i artystycznej, lecz także gospodarczej dla sporej grupy osiedlających się tam czasowo lub na stałe polskich emigrantów. Notabene cytowany Koźmian, wspominając swój pobyt w Saksonii

35 A.E. Odyniec, Listy z podróży, t. 1, Warszawa 1875, s. 122-123, List do Juliana Korsaka Teczen 8 sierpnia $1829 \mathrm{r}$.

36 M. Dernałowicz, Adam Mickiewicz, Warszawa 1985, s. 200.

37 W. Pol, Wspomnienie podróży, „Dziennik Mód Paryskich” 6, 1845, nr 11, s. 82. 
(był to jego pierwszy wyjazd zagraniczny), sformułował nawet opinię, że podróż do Drezna w zasadzie nie była w tych czasach podróżą zagraniczną. W pismach Hoffmanowej wielokrotnie pojawiały się więc deklaracje sympatii wobec Saksończyków i wyrazy zachwytu nad lokalnym krajobrazem oraz przejawy zainteresowania saską tradycją i kulturą.

W początkowych partiach relacji z wyprawy do Saskiej Szwajcarii autorstwa Hoffmanowej, podobnie jak we wspomnieniach Koźmiana, wyraźnie wybrzmiewa zachęta, nieledwie obligacja skierowana do wszystkich odwiedzających Drezno do przedsięwzięcia wycieczki w Góry Połabskie:

Ktokolwiek przyjeżdża z ciekawości do Drezna, lub też bawi w nim czas niejaki, wielkiej pozbawia się przyjemności, (zwłaszcza jeśli prawdziwej nie zna Szwajcarii) kiedy nie poświęci dwóch lub trzech dni na zwiedzanie romantycznej okolicy zwanej Szwajcarią Saską. Jest to kraina miłej, uroczej piękności, są miejsca zachwycające. Ale ponieważ są to jedynie piękności natury, miejsca wymagające raczej obrazów niżeli opisów, w dokładne ich wyszczególnienie wdawać się nie będę ${ }^{38}$.

Opis trasy, którą Hoffmanowa jak jej poprzednicy pokonała w towarzystwie przewodnika wynajętego w Lohmen, zawiera propozycję modelowego szlaku i wykaz najciekawszych, godnych zobaczenia, atrakcyjnych obiektów turystycznych. W edycji z 1862 roku został on wzbogacony licznymi rycinami przedstawiającymi spektakularne widoki i malownicze struktury skalne charakterystyczne dla tamtejszych gór stołowych. W komentarzach odnoszących się do Saskiej Szwajcarii, podobnie jak w partiach koncentrujących się na Dreźnie, pojawiły się również refleksje na temat historycznych polsko-saskich związków politycznych i ekonomicznych. We fragmencie poświęconym Lohmen Hoffmanowa zanotowała na przykład: „Jest to małe miasteczko, lecz więcej sielskie od wielu wsi saskich; zaleca się pięknym kościołem, sławną owczarnią królewską, która i do Polski niemało dostarczyła merynosów, i starym zamkiem"39.

Typowo górską pieszą wędrówkę Hoffmanowa tradycyjnie rozpoczęła we wsi Ottowalde. Już w pierwszych partiach opisu owej wycieczki na plan pierwszy wysunęly się pozytywne emocje wyzwolone dzięki obcowaniu z pięknem bujnej przyrody. Akcent został położony na manifestację zachwytu wywołanego osobliwym urokiem zaskakująco urozmaiconych skalnych formacji geologicznych:

Tu zaczyna się długi i piękny parów wśród dwóch pasm wysokich skał, którego środkiem płynie skromny strumyk. Schodzi się w ten parów po 114 schodach, a wstąpiwszy w to odludne miejsce gdzie powietrze czyste i nieskażone, miłe i szczególne obejmuje uczucie; zdaje się, że to kraina nie z tego świata, ulica jakiegoś zaczarowanego miasta; skały rozmaitego

${ }^{38}$ K. z Tańskich Hoffmanowa, Drezno i jego okolice przez..., wydanie nowe ozdobione 45 drzeworytami, Bruksela 1862, s. 277.

39 Ibidem, s. 278. 
kształtu i barwy, to nagie, to obrosłe trawą i drzewami, tworzą zupełnie jak dwie ogromne połacie dziwacznych domów; wiele z nich ma nazwy stosowne do podobieństw jakie wystawiają ${ }^{40}$.

Obiektem dostarczającym nadzwyczajnych wrażeń zmysłowych, przede wszystkim wzrokowych, także w wypadku Hoffmanowej okazała się Bastei z efektowną platformą widokową. Rozległy widok, który rozpościerał się ze szczytu, wywarł na autorce wrażenia podobne do opisywanych przez jej poprzedników:

Bastej na spłaszczonym i dosyć obszernym szczycie skały będąca składa się z kilku domostw, altan i zasadzeń; ale najcelniejszą jej ozdobą jest ogromna jakby wystawa, czy wieża z kamienia. Nad samą Elbą o 700 stóp nad poziom, wznosi się i wystaje słup ze skały; powierzchnia jego zupełnie gładka, kształt prawie okrągły, w około mocna, żelazna krata. Gdym wstąpiła na ten ganek i ujrzała obszerny i piękny widok, byłam zdumiona, — i nie wiem, czy to przypisać nowości, ale już nic w Szwajcarii Saskiej tak mnie nie zajęło ${ }^{41}$.

Z opisu tej autorki jasno wynika, że w połowie 1832 roku w pobliżu platformy widokowej Bastei funkcjonowała już całkiem pokaźna infrastruktura turystyczna, z której licznie tam przybywający turyści chętnie korzystali. Pobyt Hoffmanowej w tym atrakcyjnym miejscu przedłużył się do kilku godzin i miał typowo rekreacyjny charakter. W relacji pojawiły się w związku z tym szczegółowe informacje o tej przestrzeni, poparte wiedzą autopsyjną. Hoffmanowa wspominała na przykład o znajdujących się tam szczątkach historycznej architektury i ruinach dawnego zamku oraz o funkcjonalności zawieszonego między strzelistymi skałami drewnianego mostu, który został tam wybudowany i udostępniony turystom w 1826 roku. W przypisie do brukselskiej edycji Drezna i jego okolic dodano informację o późniejszej przebudowie owego mostu, ukończonej w 1851 roku. Stara drewniana konstrukcja została wówczas zastąpiona istniejącym do dzisiaj mostem z piaskowca, współcześnie postrzeganym jako jedna z największych atrakcji turystycznych Saskiej Szwajcarii. W pierwszym dniu wycieczki Hoffmanowa zwiedziła jeszcze położoną obok Bastei miejscowość Rathen, widziała opisywany przez poprzedników diabelski most i wilczy loch. Na nocleg, podobnie jak Koźmian, zatrzymała się w Schandau, gdzie zwróciła uwagę na znane od pierwszej połowy XVIII wieku lokalne wody mineralne.

Drugiego dnia wycieczki Hoffmanowa dotarła do doliny Lichentheim, która przypominała jej okolice Prądnika. W drodze na Kuhstall skorzystała z usług „noszowych” — lokalnych tragarzy, co następnie opisała w sposób barwny i sugestywny:

W Lichentheim, gdzieśmy wysiedli, dosyć ładny jest wodospad, ale parę groszy potrzeba, ażeby zaszumiał; koło niego stoją wygodne krzesła i kil-

40 Ibidem, s. 278-279.

${ }^{41}$ Ibidem, s. 280-281. 
ku ludzi czekających niecierpliwie, ażeby podróżny jaki słabych nóg lub piersi zanieść im się kazał na pobliskie góry. Nie wiem, czy to dobrze, czy nie, ale ci ludzie nie myślą o żadnym poniżeniu i widzą jedynie w swoim rzemiośle zamianę sił i pieniędzy. Wraz z uprzejmą towarzyszką podróży, korzystałam z dobrej ich chęci i ponieśli nas na przemiany na górę Kuhstall zwaną ${ }^{42}$.

Szczyt Kuhstall okazał się dla Hoffmanowej miejscem doznań nieledwie metafizycznych i hierofanicznych. W nieco naiwnej konwencji pisała w związku z tym, że wśród tamtejszych skał czuje się obecność Boga, ich układ i architekturę porównywała zaś do skamieniałego miasta. W otaczającym ją krajobrazie dostrzegała jednak także drobne mankamenty - brak wody i ptactwa. W narracji odwoływała się również do wzbogaconej podczas wędrówki erudycji, przytaczając genezę nazwy Kuhstall i prezentując lokalne legendy ajtiologiczne. Dalszą wycieczkę w kierunku Czech na Winterberg uniemożliwiła jej panująca w tym czasie na terenie Czech epidemia cholery — nawet krótki pobyt w tym kraju wymagał wówczas odbycia pięciodniowej kwarantanny. Co ciekawe, autorzy brukselskiej edycji Drezna i jego okolic zdecydowali się na wzbogacenie i uzupełnienie narracji Hoffmanowej czterema sztychami przedstawiającymi atrakcyjne miejsca, których Hoffmanowa nie zdołała zwiedzić ze względu na ową epidemię.

W końcowych partiach podróży autorka wspomniała jeszcze o samodzielnym wejściu (bez wsparcia tragarzy) na Lilienstein. Po osiągnięciu celu po raz kolejny uległa urokowi rozległego widoku. Dokonując w tej sytuacji autoanalizy własnych emocji i doznań, odwoływała się do tradycji profetycznej i wiedzy o kondycji proroków doznających objawień na wyniosłych szczytach. Na drugi nocleg wybrała Königstein, skąd jadąc przez Pirnę, wróciła do Drezna.

Literackie ślady peregrynacji po Saskiej Szwajcarii zachowały się także w twórczości poetyckiej Bogusza Zygmunta Stęczyńskiego, który swoją podróż wzdłuż koryta Łaby odbył najprawdopodobniej na początku lat pięćdziesiątych XIX wieku. Owocem jego wędrówki przez Śląsk i Saksonię był poemat Polska Najada, czyli głos wodospadu Łaby na Szlasku, odnaleziony i ogłoszony drukiem dopiero w 1998 roku przez Jacka Kolbuszewskiego. We wstępie do pierwszego wydania Najady czytamy, że

koncepcję tego utworu wysnuł [...] autor z wcześniejszego pomysłu zawartego w piątej pieśni Sudetów. Opisał w niej urodę karkonoskich źródeł i wodospadów Łaby i opis ten zwieńczył „przytoczeniem” pieśni owej rzeki. Ta właśnie pieśń stała się zalążkiem pomysłu Polskiej Najady ${ }^{43}$.

Stęczyński był autorem kilku poematów opisowych: Tatry (1860), Ślask (ogłoszony drukiem dopiero w 1949 roku we Wrocławiu przez Franciszka Pajączkow-

42 Ibidem, s. 288.

43 J. Kolbuszewski, „Polska Najada, czyli głos wodospadu Łaby na Szlasku” - nieznany poemat Bogusza Zygmunta Stęczyńskiego, „Annales Silesiae” 28, 1998, s. 6. 


\title{
Polska Najada
}

\author{
chyli \\ glos wodospoidu faby
na Jxlasku. \\ Fantaryja historyana \\ Boguesra Rygmecnta \\ Ifscryniskiegas \\ Pogrórinika po krajach Stawianskich, \\ antora Oholic Galicyi. Tatrów, Sivigtymi Polakiow, \\ 6. Bibliotekarka sp. Mixaryot: hr. Driedusryakiega.

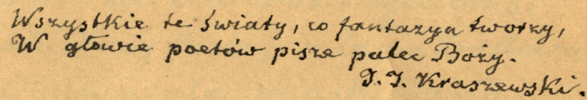

4. Karta tytułowa rękopisu Polskiej Najady, zbiory prywatne Jacka Kolbuszewskiego

skiego) i Sudety jako dalszy ciag poematu Tatry (pierwodruk: 1982). Dwa ostatnie powstały jako owoc podróży Stęczyńskiego po Śląsku, odbytej przez niego najprawdopodobniej w 1851 roku. Jak wykazały współczesne badania, poeta swoje poematy wielokrotnie przerabiał, a także dopisywał do nich nowe partie. Polska Najada została ukończona prawdopodobnie dopiero w 1882 lub nawet 1886 roku. Jacek Kolbuszewski zauważył, że 
Osobliwość dziejów powstania Polskiej Najady polega jednak i na tym, że ów pomysł zarysowany w Sudetach Stęczyński po raz pierwszy wykorzystał w rękopiśmiennym dziele swoim zatytułowanym Osobliwości krajów i okolic stowiańskich, które w 1879 r. ofiarował, bardziej na pewno licząc na gratyfikacje bądź na druk, niż pragnąc okazać lojalistyczno-wiernopoddańczą postawę, do Biblioteki Cesarskiej w Wiedniu. Z Wiednia jednak otrzymał tylko kilka zdawkowych uprzejmości, z daru najmniejszych korzyści zaś nie wyniósł. Około natomiast roku 1886 jego sytuacja materialna była już bardzo trudna, los jego zaś po śmierci jedynego syna można określić mianem tragicznego. Podjął wtedy Stęczyński rozpaczliwą jedną jeszcze próbę druku swego dzieła, w którym elementy koniunkturalnie przemyślanego lojalizmu przeplatają się z wyrazami najgłębszego i autentycznego patriotyzmu ${ }^{44}$.

Poemat Stęczyńskiego wpisuje się zatem w koncepcję jego pielgrzymek po kraju i po Słowiańszczyźnie, które - niepozbawione romantycznej ideologii, potrzeby poszukiwania śladów własnej kultury i tradycji plemiennej w Europie - miały także walory krajoznawcze. Co dla nas istotne, w odnalezionym po latach utworze rekonstruował on szlak peregrynacji po Saskiej Szwajcarii, wiodący wzdłuż Łaby.

W wypadku wędrówki Stęczyńskiego mamy do czynienia z innym od opisanych wcześniej kierunkiem zwiedzania i modelem szlaku, który najczęściej rozpoczynał się w okolicach Drezna - w utworze Stęczyńskiego punktem inicjalnym jest bowiem Klacko (Kłodzko). Integralną, istotną w kontekście badań nad recepcją krajobrazu i kultury Saskiej Szwajcarii, część poematu stanowi Pieśń Najady, znana także jako Pieśń Łaby. Jak zauważył Kolbuszewski, tytuł Najada jest aluzją do tradycji antycznej - nawiązanie do wątku nimfy mieszkającej na górze Ida, którą za żonę pojął król Kapis, a ta następnie zamieniła się w źródło Nais ${ }^{45}$. Łabę Stęczyński zinterpretował jako rzekę polską, gdyż według niego płynie ona przez ziemie historycznie polskie. W odróżnieniu od zaprezentowanych wcześniej relacji z wędrówek po Szwajcarii Saskiej omawiany poemat manifestuje niechęć do Niemców i kultury niemieckiej przy jednoczesnym wyraźnie eksponowanym lojalizmie austriackim. W tym kontekście poeta powoływał się na słowianofilskie koncepcje Jana Kollára i politykę historyczną Bolesława Chrobrego.

Odwrotny niż wszystkie dotychczasowe kierunek zwiedzania Saskiej Szwajcarii jest zgodny z nurtem Łaby i stanowi konstrukcyjną oś narracji oraz przestrzennej koncepcji utworu. Peregrynacja po jej obszarze - w tym wypadku realizowana w dużej części jako żegluga - rozpoczyna się w Dieszynie (niem. Tetschen, czes. Děčín). W pierwszej kolejności Stęczyński zwrócił uwagę na tamtejszy zamek, a nawet jego estetyczne wyposażenie oraz ulokowaną na tym tere-

44 Ibidem, s. 7.

45 Ibidem, s. 13. 
nie kolekcję posągów, obrazów oraz interesujących eksponatów przyrodniczych. Zmieniający się podczas żeglugi krajobraz został opisany selektywnie. Stęczyński wymienił liczne widoczne podczas spływu znane obiekty: „Królewską skałę”, czyli twierdzę Königstein, „Lilii Skały”, czyli Lilienstein, oraz skały Baszty, a więc słynną Bastei. Co znamienne, topograficzne nazwy lokalne autor podawał tylko w polskiej transkrypcji. Niemniej należy podkreślić, że wprowadzony do poematu opis Bastei, choć naiwnie nieudolny, jest pierwszym polskim poetyckim opisem tej turystycznej atrakcji, zawiera zresztą interesujące uwagi o rozwiązaniach architektonicznych zabezpieczających pobyt na tamtejszej platformie widokowej i ułatwiających wygodne poruszanie się po trudnym i wymagającym specjalnych umiejętności terenie:

Po drugiej stronie Lilii Skały, Odbijam w moim żywiole;

I dumnej Baszty obraz spaniały

Maluję na moim czole.

Baszta jest sobie skała wyniosła, Poglądać na dół z jej szczytu,

Wzbudza obawę, chociaż porosła

Mchem, pełnym swego rozkwitu.

Baszta, szczególną będąc opaską, Sięga ku niebu swym czołem I rozpiera się dumna szeroko Pyszniąc się ciałem swym gołym.

Ona na skraju swej wysokości

Mając żelazne poręcza;

Do używania tam przyjemności

Łatwą sposobność nastręcza.

Miłośnik ceniąc wdzięki przyrody

Bezpiecznie się tam nachyla

I patrzy w przepaść, bo bez przeszkody

Wszystko tak się tam wysila.

Dla jego oka swymi tworami

Że ku czci słów mu brakuje!

Tylko wzruszeniem i uczuciami

Wszystko, za święte, szanuje.

Przyroda w rannym słońcu przybiera

Złoto-różową powłokę; 
I tak cudowny urok wywiera

I tak myśl wzbudza głęboką ${ }^{46}$.

Nacechowany emocjonalnie szczegółowy opis wrażeń związanych z przestrzenią rozciągającą się wokół skał Bastei świadczy o tym, że Stęczyński był kolejnym Polakiem odwiedzającym to miejsce w XIX wieku. Godny uwagi wydaje się także jego świadomy i dojrzały sposób reagowania na przyrodę i krajobraz, o tyle romantyczny, o ile preruskinowski. W rękopiśmiennej wersji Najady (obecnie przechowywanej w rękach prywatnych) znajduje się także kilka sztychów przedstawiających wybrane obiekty Saskiej Szwajcarii, między innymi Königstein i Bastei, co jest typowe dla bliskiej Stęczyńskiemu koncepcji sztuki i uprawianego przez niego stylu twórczości z położeniem silnego akcentu na stały dialog między obrazem a tekstem.

Problematyka obecności Polaków w Górach Połabskich, zwłaszcza w słynnej Saskiej Szwajcarii, nie została jak dotąd omówiona w szerszym zakresie. Przedstawiony szkic ma charakter rekonesansu badawczego. Jak wykazała analiza zgromadzonego materiału egzemplifikacyjnego, w pierwszej połowie XIX wieku te niewysokie góry Europy Środkowej były przez Polaków chętnie odwiedzane i ruch turystyczny na ich obszarze wyraźnie wpisuje się w historię polskiej turystyki górskiej. Ze względu na osobliwe walory estetyczne i przyrodnicze inspirowały one nie tylko wyobraźnię twórców niemieckojęzycznych, lecz także polskich romantyków. Jak wynika z omówionych relacji pamiętnikarskich i podróżniczych, odgrywały również ważną rolę w kształtowaniu wyobraźni przestrzennej polskich turystów oraz wrażliwości estetycznej na nieregularny krajobraz. Dziewiętnastowieczne mikrowyprawy Polaków do Saskiej Szwajcarii miały też pewien wpływ na rozwój polskiej turystyki górskiej na poziomie popularno-rekreacyjnym. Z kolei same polskojęzyczne relacje $\mathrm{z}$ wycieczek po tym regionie są godnym uwagi przejawem początków polskiej literatury podróżniczo-wyprawowej.

\section{Bibliografia}

Dernałowicz M., Adam Mickiewicz, Warszawa 1985.

Deszert S., Dziennik podróży odbytej w latach 1828 i 29 przez S.D., rękopis Biblioteki Zakładu Narodowego im. Ossolińskich, sygn. II 3585.

Domańska E., Mikrohistorie. Spotkania w międzyświatach, Poznań 1999.

Hoffmanowa z Tańskich K., Drezno i jego okolice przez..., wydanie nowe ozdobione 45 drzeworytami, Bruksela 1862.

Irving A., Podróże dalekie i bliskie. Roz-czarowanie percepcja, wiedza i ciatem, przeł. S. Sikora, „Teksty Drugie” 2018, nr 1, s. 173-199.

Ismer S., Peter N., „,Das alles ist Teil einer Reise zu sich selbst” — Grenzerfahrungen als identitätsstiftendes Moment in zeitgenössischen Autobiographien von Bergsteiger ${ }^{*}$ innen / „To wszystko jest częścia podróży do samego siebie” — doświadczenia graniczne jako moment kształtujacy tożsamość we wspótczesnych autobiografiach wspinaczy, „Góry - Literatura Kultura" 11, 2017, s. 377-397.

46 Ibidem, s. 21-22.

Góry - Literatura - Kultura 12, 2018

(C) for this edition by CNS 
Jaworski K., Turystyka polska w czeskich Sudetach w XVIII i XIX wieku, „Góry - Literatura Kultura" 3, 1998, s. 9-19.

Keiser W., Od Rugii do Saskiej Szwajcarii, Warszawa 1989.

Kolbuszewski J., ,Polska Najada, czyli głos wodospadu Łaby na Szlasku” - nieznany poemat Bogusza Zygmunta Stęczyńskiego, „Annales Silesiae” 28, 1998, s. 6-42.

Koźmian A.E., Dwa dni w Szwajcarii Saskiej, Warszawa 1828.

Koźmian A.E., Wspomnienia, t. 1. Pamiętniki z dziewiętnastego wieku, Poznań 1867.

Liebe S., Kempe L., Säc hsische Schweiz und Ausfl üge in die Böhmische Schweiz, Leipzig 1974.

Krajina - maska prírody? Studie k estetice krajiny a environmentu, red. K. Stibral, V. Faktorová, České Budějovice 2015.

Odyniec A.E., Listy z podróży, t. 1, Warszawa 1875.

Odyniec A.E., Wspomnienia z przeszłości opowiadane Deotymie przez..., Warszawa 1884.

Pol W., Wspomnienie podróży, „Dziennik Mód Paryskich” 6, 1845, nr 11, s. 82.

Stibral K., Hory a divočina jako nový ideál krajiny. K proměně estetické hodnoty hor v 18. století, referat wygłoszony na konferencji z cyklu „Góry - Literatura - Kultura”, Idealizacja gór: przyroda, człowiek, kultura, Polanica-Zdrój 7-9 listopada 2018, maszynopis udostępniony przez autora.

\section{Źródła internetowe}

https://de.wikipedia.org/wiki/S\%C3\%A4chsische_Schweiz (dostęp: 30.01.2019).

https://www.saechsische-schweiz.de/malerweg/wanderweg-malerweg/geschichte.html (dostęp: 30.01.2019).

https://www.saechsische-schweiz-tipp.de/geschichte-tourismus.html (dostęp: 30.01.2019). 